УДК 613.6 : [628.8.331.442.4]

\title{
STUDIES ON MICROCLIMATE OF OFFICE PREMISES AND IMPROVEMENT OF ITS HYGIENIC REGULATION IN UIKRAINE
}

\author{
Nazarenko V. I., Cherednichenko I. M., Soloviev O. I., \\ Nykyforuk O. I., Tereshchenko P. S.

\section{State Institution «Institute for Occupational Health of the National Academy of Medical Sciences of Ukraine», Kyiv}

Introduction. Microclimate of office premises is an important factor of the work environment for office employees, requiring creation of optimal work conditions and developing preventive measures.

The purpose of the study was to establish the influence of office microclimate on indicators of employees' thermal state and their subjective evaluation of the thermal environment, to identify further improving of hygiene regulations.

Materials and methods. The studies on work conditions were conducted in warm and cold periods of the year, according to requirements of normative documents, at 180 work places of office workers (engineers, programmers, systems administrators, heads of sectors, task administrators, electronic engineers, engineers of telecommunication) at enterprises and public institutions in the city Kyiv. The study of the human thermal state (HTS) with subjective evaluation of the comfort constituent of the thermal environment was carried out in warm (June - August) and cold seasons (December - February) covering 112 office employees, according to Methodical recommendations № 5168-90.

Results. It is established that the temperature at workplaces of office workers exceeds the permissible temperature ranges by $1,2-2,4^{\circ}$ Caccording to the sanitary norms for microclimate in Ukraine, but meets the requirements of the ISO 7730:2005 for the thermal environment of the categories B and C (sensation of the thermal discomfort no more than in $10 \%$ and $15 \%$ of users, respectively). It is revealed that at the standard workplace of an office worker the total heat emission makes $452,3 \mathrm{kcal} / \mathrm{h}$ or $530 \mathrm{~W}$. At the same time, for a person engaged in office work, it makes $48 \%$ of the total heat emission, on the average, and for the office equipment $-52 \%$. Basing on the questioning, a relation between the thermal sensation of office workers and the air temperature in office premises in warm and cold seasons was calculated. There are proposed measures for creating comfortable microclimatic conditions for office workers.

Conclusion. The thermal sensation assessment in office workers shows that the upper threshold for uncomfortable air temperature at work places in the warm period (in summer) is more than $27^{\circ} \mathrm{C}$, in the cold period (in winter) - more than $24^{\circ} \mathrm{C}$. There is a need to revise The Sanitary norms on microclimate 3.3.6.042-99 in respect of its optimal parameters, taking into account methodological approaches of the State Sanitary technical specifications 7730:2011,in respect of the definition of categories of premises and a number of unsatisfied persons. In order to maintain optimal parameters of the relative air humidity in office it is recommended to use ultrasonic humidifiers of Vitek VT-1762W type for normalization of the air ionic content in office premises.

Key words: microclimate, office premises, hygienic regulation

\section{Introduction}

In Ukraine there are over 2 million office workers, engaged in business, public administration, finance, banking, etc [1]. In the complex of the environmental factors, affecting office workers, parameters of microclimate play an important part in combination with the strain work, and, so, need creation of optimal microclimate conditions [2-5]. According to the Ukrainian Sanitary Norms DSN 3.3.2.007-98 and ISO 9241: 2004 «Ergonomic requirements for works with video terminals in the office» and the literature data, methodical approaches to organization of a workplace for office workers are proposed [6, 7]. However, the effect of micro-climatic conditions requires further studies, with due account of implementation of new technologies for controlling the microclimate [8-10]. In assessing the comfort of the microclimate the assessment of a subjective human response to the thermal environment is very important, according to the international standards ISO 7730 «Ergonomics of the thermal environment», which has been implemented in Ukraine as an identical translation (IDT) for the voluntary use in Ukraine [11].

The purpose of the study - to establish the influence of the microclimate in office premises on indicators of employees' thermal state and on their subjective assessment of the thermal environment, to identify further improving of hygiene regulations. 


\section{Materials and methods}

The sanitary and hygienic studies on work conditions were conducted in warm and cold periods of the year, according to the current regulatory documentation, at 180 workplaces of office workers (engineers-programmers, system administrators, heads of sectors, group leaders, task administrators, electronic engineers, telecommunication engineers) at enterprises and public institutions of the city Kyiv: JSC «Ukrtelecom», Ministry of infrastructure of Ukraine, «Kyiv Contact Centre», Commercial enterprise «Gospkomobslugovuvannya», CardSystems Ltd. Measurements of the microclimatic parameters were made with the ball thermometer Tensor-41 (Ukraine) and the anemometer TESTO 405-V1. The study of the human thermal state (HTS) with the subjective assessment of the comfort in the work environment was carried out in the warm season (June - August) and the cold season (December - February) in 112 workers, according to Methodical Recommendations № 5168-90 [12]. The statistical analysis of the data was performed with the use of the standard programs Microsoft Office Excel 2007, Statistics 10, installed in the software of the PC.

\section{Results and discussion}

The work in modern offices is characterized by that, premises, as usual, are located in multi-storey buildings, where a variety of climate control systems, chillerfan coil units, split systems, and others, are used. The area per one workplace is from $3-5 \mathrm{~m}^{2}$ (for the engineering personnel, economists, and others) to $12-16 \mathrm{~m}^{2}$ (for the managerial team), the volume from $10,4 \mathrm{~m}^{3}$ to $41,6 \mathrm{~m}^{3}$, respectively. In premises for call-centers 23-75 persons can work simultaneously. For air conditioning in warm seasons in some premises there are used mainly split-systems, like Samsung, Daikin and others, with areas $20-25 \mathrm{~m}^{2}$ for effective cooling or heating. In premises, where the air conditioning system (ACS) has not been installed, in warm seasons under high air temperature of $28-30{ }^{\circ} \mathrm{C}$ and higher, windows are often open and floor or wall fans are used, causing strong draughts at work places. In cold periods in order to maintain standard microclimatic parameters district heating and ventilation are used.

One of the major technical solutions for normalization of microclimatic conditions is implementation of effective systems of air conditioning. Thus, when a chiller-fan coil system for the total control of microcli- matic conditions is operating the temperature was maintained within $22,7-26,6{ }^{\circ} \mathrm{C}$, relative humidity $38-70 \%$, air velocity $-0,01-0,22 \mathrm{~m} / \mathrm{s}$. In this, work conditions by temperature indices at $23 \%$ workplaces corresponded to Class 2 (permissible work conditions) whereas at $77 \%$ workplaces - to Class 3.1 (harmful), by the acting Hygienic Classification of Labor (2014).

At $65 \%$ work places the relative humidity corresponded to Class 2 (permissible work conditions) and at $35 \%$ workplaces - to Class 3 (harmful). The air velocity did not meet standards only at $6 \%$ workplaces.

In premises with split systems the air temperature ranged $25,2-26,4{ }^{\circ} \mathrm{C}$, the relative humidity was $51-$ $55 \%$, air velocity $0,05-0,24 \mathrm{~m} / \mathrm{s}$. In this, according to the temperature indices work conditions at $100 \%$ workplaces corresponded to Class 3.1 (harmful). The relative humidity met Class 2 (permissible work conditions) at $100 \%$ work places. The velocity of the air in $80 \%$ met Class 2 (permissible) and $20 \%$ - to Class 3.1 (harmful work conditions). These values exceed the range of permissible temperatures $\left(22-24{ }^{\circ} \mathrm{C}\right)$ by $1,2-2,4{ }^{\circ} \mathrm{C}$ according to acting Sanitary Norms on microclimate 3.3.6.042-99, but, according to the International Standard ISO 7730 they are quite acceptable for the thermal environment in premises of categories $\mathrm{B}$ and $\mathrm{C}$ (sensation of the temperature discomfort no more than in $10 \%$ and $15 \%$ individuals, respectively). Moreover, a rather narrow range of temperature regulation for indoor air for office workers $21-23{ }^{\circ} \mathrm{C}$ in winter and $22-24{ }^{\circ} \mathrm{C}$ in summer for physical work « $1 \mathrm{~b}$ » according to the Sanitary Norms 3.3.6.042-99 is a subject of further discussion.

According to the obtained data, the main sources of permanent heat emission within a year in office premises are workers themselves and the office equipment (table 1).

Thus, in the category «1b» an office worker produces $140-174 \mathrm{~W}(121-150 \mathrm{kcal} / \mathrm{h})-30 \%$ of the total heat emission at workplace, heat emission of the main metabolism in a human body is $(95,7 \pm 1,8) \mathrm{W}$ $(81,8 \pm 1,5 \mathrm{kcal} / \mathrm{h})-18 \%$ of the total heat emission.

The studies on the heat emission from the technical equipment shows that a system computer unit produces $188 \mathrm{kcal} / \mathrm{h}-26 \%$ of the total at a workplace, a videomonitor $-30 \mathrm{kcal} / \mathrm{h}(7 \%)$ and MFC- $85 \mathrm{kcal} / \mathrm{h}(19 \%)$ of the total heat production at workplace.

Generally, the heat emission of a office worker due to the main metabolism and physical work makes, on the average, $217,3 \mathrm{kcal} / \mathrm{h}$ ( $48 \%$ of the total heat 
The main sources of permanent heat emission at an ordinary workplace

\begin{tabular}{|c|c|c|c|c|}
\hline \multirow[b]{2}{*}{ Source of heat emission } & \multicolumn{3}{|c|}{ Energy consumption } & \multirow{2}{*}{$\begin{array}{l}\text { Percentage of the } \\
\text { total number }\end{array}$} \\
\hline & W & $\mathrm{kcal} / \mathrm{h}$ & $\begin{array}{c}\text { average, } \\
\mathrm{kcal} / \mathrm{h}\end{array}$ & \\
\hline \multicolumn{5}{|c|}{ A human } \\
\hline $\begin{array}{l}\text { Easy physical work, categor «1b» } \\
\text { (Sanitary Norms } 3.3 .6 .042-99 \text { ) }\end{array}$ & $140-174$ & $121-150$ & 135,5 & $30 \%$ \\
\hline Metabolic rate & $95,7 \pm 1,8$ & $81,8 \pm 1,5$ & 81,8 & $18 \%$ \\
\hline \multicolumn{3}{|l|}{ In general } & 217,3 & $48 \%$ \\
\hline \multicolumn{5}{|c|}{ Technical equipment } \\
\hline $\begin{array}{l}\text { The system unit Intel Pentium Dual } \\
\text { Core E6 } 600\end{array}$ & $\begin{array}{c}\text { at work }-110, \\
\text { at rest }-63\end{array}$ & $\begin{array}{c}\text { at work }-129(80 \% \text { shift time }) \\
\text { at rest }-74(20 \% \text { shift time })\end{array}$ & 118 & $26 \%$ \\
\hline Monitor View Sonic VA926 19" & 26 & 30 & 30 & $7 \%$ \\
\hline $\begin{array}{l}\text { Multi-functional unit Brother } \\
\text { MFC-7360n }\end{array}$ & $\begin{array}{c}\text { at work }-440 \text {, } \\
\text { at rest }-50\end{array}$ & $\begin{array}{c}\text { at work }-515(10 \% \text { shift time }) \\
\text { at rest }-59(90 \% \text { shift time })\end{array}$ & 85 & $19 \%$ \\
\hline \multicolumn{3}{|l|}{ In general } & 235 & $52 \%$ \\
\hline \multicolumn{3}{|l|}{ Total } & 452,3 & $100 \%$ \\
\hline
\end{tabular}

emission $-452,3 \mathrm{kcal} / \mathrm{h}$ or $530 \mathrm{~W})$, the workplace equipment $-235 \mathrm{kcal} / \mathrm{h}(52 \%)$. So, it is important to take into account square and volume of premises per one workplace in order to reduce heat accumulation in offices.

One of important indicators of the effect of the thermal environment on humans is their thermal sensation [12]. On the basis of field studies a relation between the thermal sensation of employees and the air temperature in offices has been calculated. In this, the dependence of the thermal sensation on the temperature can be described by the following equation for a warm period of the year:

$$
\mathrm{TS}, \text { score }=-6,1762+0,4126 \cdot \mathrm{T}{ }^{\circ} \mathrm{C}
$$

where TS - thermal sensation, estimated according to the criteria of the acceptable thermal state of a man (TSM) by seven-point scale, scores;

$\mathrm{T}{ }^{\circ} \mathrm{C}$ - dry bulb temperature in premises, ${ }^{\circ} \mathrm{C}$

The regression equation shows that the increase in the air temperature by $1{ }^{\circ} \mathrm{C}$ above $24{ }^{\circ} \mathrm{C}$ results in the increase of the thermal sensation by $0,4 \approx$ scores and exceeds the permissible value of the human thermal state (HTS) by 5 points in the indoor temperature above $27{ }^{\circ} \mathrm{C}$. Thus, the upper limit, when a negative impact on this subjective indicator of the thermal state in an office worker is recorded, makes $27^{\circ} \mathrm{C}$.

The dependence of the thermal sensation on the temperature in the cold season is similar to the depen- dence in the warm season and can be described by the following linear regression equation:

$$
\mathrm{TS} \text {, score }=-6,2124+0,4633 \cdot \mathrm{T}^{\circ} \mathrm{C}(2)
$$

where TS - thermal sensation;

$\mathrm{T}{ }^{\circ} \mathrm{C}-$ dry bulb temperature in premises, ${ }^{\circ} \mathrm{C}$.

In this, the upper limit, when an adverse effect of the temperature on the human body in the office premises in the cold season is recorded, is approximately $24{ }^{\circ} \mathrm{C}$. Thus, the difference in thresholds of adverse effects of the air temperature in cold and warm periods of the year indicates the availability of seasonal fluctuations in the human sensitivity to the temperature factor, which should be considered when developing prevention measures.

A percentage of persons dissatisfied with the air temperature in the cold season in offices can be calculated by the following equation regression of the linear character:

Dissatisfied persons, $\%=-316,9167+13,5 \cdot \mathrm{T}{ }^{\circ} \mathrm{C}(3)$

where $\mathrm{T}^{\circ} \mathrm{C}-$ dry bulb temperature in premises.

The equation shows that with the increase of the air temperature over $24{ }^{\circ} \mathrm{C}$ in the cold season the number of complaints linearly increases - by $13,5 \%$, with each degree in the increase of the air temperature.

In addition, there is a relation in the increase of the number of complaints on the decrease of the relative 
air humidity: in the humidity less than $26-28 \%$ more than a half of the employees expressed their complaints on the air dryness.

The formula, by which the number of persons, dissatisfied with the air humidity, can be described as follows:

Dissatisfied persons, $\%=-233,9+$ $+23,9 \cdot \mathrm{X}+0,49 \cdot \mathrm{X}^{2}$

where $\mathrm{X}$ - relative air humidity.

Based on the data of the subjective evaluation of the thermal environment, the distribution of workers by their thermal sensations at different air temperatures in premises in the cold season is shown in Figure 1.

According to the findings there is a noticeable difference in the subjective assessment of the similar thermal environment. The percentage of individuals with the thermal sensation «comfortable» at 23,0$23,9{ }^{\circ} \mathrm{C}$ was $67 \%$, for «cold» it was $6,7 \%$ and $13,3 \%$ for «warm and hot».

When the air temperature was $24,0-24,9{ }^{\circ} \mathrm{C}$, $57,7 \%$ the examined office workers evaluated the thermal environment in the premises as «comfortable», $15,3 \%$ respondents as «warm and hot» and $7,7 \%$ as «cold». In the temperature range $25,0-25,9{ }^{\circ} \mathrm{C}$, exceeding the standard sanitary norms by $2,0-2,9^{\circ} \mathrm{C}$, thermal sensations «comfortable» was recorded in $36,7 \%$ respondents, «warm and hot» in 36,7 \% and «cold» in $6,1 \%$ employees. In the temperature range $26,0-26,9{ }^{\circ} \mathrm{C}$ the thermo-sensation «cold» was recorded in $0 \%$ respondents, «comfortable» in $16 \%$, and «warm and hot» in $68 \%$ office workers.

So, the number of people, who assessed the thermal environment as comfortable, decreases significantly with the increase of the air temperature upper than the standard value. At the same time, the percent of people, who evaluated the thermal environment as «warm and hot» increased from $15,5 \%$ at $24,0-24,9{ }^{\circ} \mathrm{C}$ to $68 \%$ at $26,0-26,9{ }^{\circ} \mathrm{C}$. Under temperatures above $26,0{ }^{\circ} \mathrm{C}$ no one appreciated their thermo-sensations as «cold». In our opinion when establishing comfortable temperatures in offices it is necessary to consider subjective assessments of employees of the thermal environment.

So, in order to create comfort microclimate conditions at workplace for office workers we recommend to use methodical approaches in the practice of the national sanitary legislation, harmonized with the international standard ISO 7730 «Ergonomics of the thermal environment». In this, categories $\mathrm{A}, \mathrm{B}, \mathrm{C}$ of the thermal environment for office premises should be taken into account, according to the calculated number of persons dissatisfied with microclimate parameters (Table 2).

Based on the calculations of the number of individuals, dissatisfied with the temperature conditions, we can recommend for office premises in warm period of a year (summer) the upper limits for the air temperature as $25,5-26,0^{\circ} \mathrm{C}$ (Category of the thermal environment «B»). For cold season, when a human organism is more sensitive to the temperature factor, it is necessary to maintain the temperature within $21-23{ }^{\circ} \mathrm{C}$, which corresponds to the requirements of the national standards 3.3.6.042 and 3.2.2.007-98 and to the ISO 7730 (for the thermal environment of the category $« A »$ ).

Also, it should be noted that the real number of people, dissatisfied with the air temperature in the premises, according to our studies, is somewhat higher than those estimated by the ISO 7730 (Table 3).

This fact should be a subject of further research, taking into account other production factors, which can affect the thermal human state, e.g. work intensity $[2,14]$.

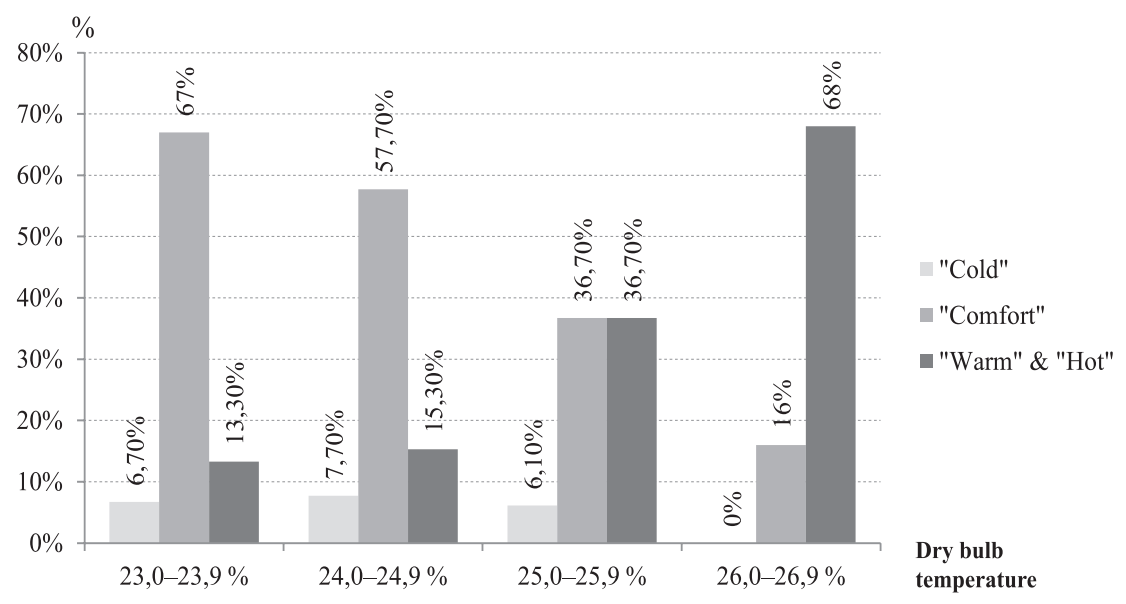

Figure 1. Distribution of office employees by their thermal sensation under different air temperatures in premises (for the cold season) 
Recommended microclimate parameters, by the ISO 7730

\begin{tabular}{|c|c|c|c|}
\hline $\begin{array}{c}\text { Category of the thermal environment(percentage } \\
\text { of dissatisfied persons (PDP) }\end{array}$ & $\begin{array}{l}\text { Air temperature } \\
\text { (dry bulb), }{ }^{\circ} \mathrm{C}\end{array}$ & \begin{tabular}{|c|} 
Relative air humidity, \\
$\%$
\end{tabular} & $\begin{array}{c}\text { Air velocity, } \\
\mathrm{m} / \mathrm{s}\end{array}$ \\
\hline $\begin{array}{l}\text { Category A } \\
(\mathrm{PDP}<6 \%)\end{array}$ & $\begin{array}{c}21-23^{\mathrm{c}} \\
23,5-25,5^{\mathrm{w}}\end{array}$ & \multirow{3}{*}{$40-60$} & $\begin{array}{c}0,1^{\mathrm{c}} \\
0,12^{\mathrm{w}}\end{array}$ \\
\hline $\begin{array}{l}\text { Category B } \\
(\mathrm{PDP}<10 \%)\end{array}$ & $\begin{array}{l}20-24^{\mathrm{x}} \\
23-26^{\mathrm{w}}\end{array}$ & & $\begin{array}{l}0,16^{\mathrm{c}} \\
0,19^{\mathrm{w}}\end{array}$ \\
\hline $\begin{array}{l}\text { Category C } \\
(\mathrm{PDP}<15 \%)\end{array}$ & $\begin{array}{l}19-25^{\mathrm{c}} \\
22-27^{\mathrm{w}}\end{array}$ & & $\begin{array}{l}0,21^{\mathrm{c}} \\
0,24^{\mathrm{w}}\end{array}$ \\
\hline \multicolumn{4}{|c|}{ Requirements of the State Sanitary Standard 3.6.042-99 } \\
\hline Category of physical work «1a» & $\begin{array}{l}22-24^{\mathrm{c}} \\
23-25^{\mathrm{w}}\end{array}$ & $40-60$ & $\begin{array}{l}<0,1^{\mathrm{c}} \\
<0,1^{\mathrm{w}}\end{array}$ \\
\hline Category of physical work «1b» & $\begin{array}{c}21-23^{\mathrm{c}} \\
22-24^{\mathrm{w}}\end{array}$ & $40-60$ & $\begin{array}{l}<0,1^{\mathrm{c}} \\
<0,1^{\mathrm{w}}\end{array}$ \\
\hline
\end{tabular}

Note: ${ }^{c}$ cold season; ${ }^{w}$ warm season.

The use of domestic and professional ultrasonic humidifiers of VitekVT-1762W type with an area of humidification to $25 \mathrm{~m}^{2}$ and water consumption of $250 \mathrm{ml} /$ year was recommended in order to maintain the optimum humidity in office premises. According to the data of field studies it is found that under the operation of the humidifier with the above-mentioned characteristics, the ionic content in the air normalizes in 5-10 minutes, which meets the Sanitary Normative № 2152-80 $\left(\mathrm{a}^{+}>\right.$ 400 unit $/ \mathrm{cm}^{3}, \mathrm{a}^{-}>600$ unit/ $\mathrm{cm}^{3}$ ) and remain for 30 minutes after switching off the device $(p<0,05)$.

The implementation of the ISO 7730 on microclimatic parameters into practice of the health surveillance in Ukraine should be made in accordance with the Resolution of the Cabinet of Ministers of Ukraine № 440 of 13.06 .95 «On approval of provisions on hygienic regulation».

\section{Conclusions}

1. The specificity of the microclimate in office premises is the exceeding of permissible air temperatures by $1,2-2,4{ }^{\circ} \mathrm{C}$, even under the running system of the air conditioning, that requires further researches based on subjective evaluations of the thermal comfort environment for office workers.
2. At the standard workplace for an office worker the total heat emission makes $452,3 \mathrm{kcal} / \mathrm{h}$ or $530 \mathrm{~W}$, on the average. In this, the emission of the human body makes $48 \%$ of the total, and that of the office equipment $-52 \%$. Therefore, it is very important to take into account the area and volume of premises for each workplace, installation of effective systems of ventilation and air conditioning, which can help to reduce heat accumulation in the working premises.

3. According to the assessment of the thermal sensations of office workers, the upper threshold of the uncomfortable temperature in office premises in the warm period (summer) of a year is over $27^{\circ} \mathrm{C}$, in the cold (in winter) - more than $24^{\circ} \mathrm{C}(\mathrm{p}<0,05)$.

4. It is necessary to revise Sanitary Norms on Microclimate 3.3.6.042-99 in terms of their optimal parameters, taking into account methodological approaches of the ISO 7730 in respect of the thermal environment in office premises with due account of the number of dissatisfied persons.

5. In order to maintain optimum parameters on the relative humidity in office premises it is recommended to use ultrasonic humidifiers of VitekVT$1762 \mathrm{~W}$ type for normalization of the ionic content in the indoor air.

The number of persons dissatisfied with the thermal environment (cold season)

\begin{tabular}{|c|c|c|c|c|}
\hline \multirow{2}{*}{$\begin{array}{l}\text { The number of persons dissatisfied with the air tem- } \\
\text { perature in the premises }\end{array}$} & \multicolumn{4}{|c|}{ Air temperature at workplace, ${ }^{\circ} \mathrm{C}(\mathrm{N}=115$ respondents) } \\
\hline & $23,0-23,9$ & $24,0-24,9$ & $25,0-25,9$ & $26,0-26,9$ \\
\hline $\begin{array}{l}\text { Estimated number of dissatisfied persons in accordance } \\
\text { with the ISO } 7730, \%\end{array}$ & $<10$ & $<15$ & \multicolumn{2}{|c|}{$>15$} \\
\hline $\begin{array}{l}\text { The number of dissatisfied persons by the data of the } \\
\text { studies }(X \pm m), \%\end{array}$ & $20,0 \pm 3,7^{*}$ & $23,0 \pm 3,9 *$ & $42,8 \pm 4,6$ & $68,0 \pm 4,4$ \\
\hline
\end{tabular}

Note: ${ }^{*} p<0,05$ 


\section{References}

1. Statistical book "Work in Ukraine in 2014", State service on statistics in Ukraine. Kyiv, 2015, 280 p. (in Ukrainian).

2. Kundiiev, Yu. I. 2002, Occupational health - a five decade experience. Kyiv : "Avicenna", 672 p. (in Russian).

3. Rubtsov, M. Yu., Matyukhin, V. V., Rubtsova, N. B. et al. 2012, "A combined study on the effect of peculiarities of the work environment on physiological and psychological states of office workers", Med. truda i prom. ekologia, no. 4, pp. 9-13 (in Russian).

4. Nazarenko, V. V., Tereschenko, P. I., Levchenko, L. O. et al. 2013, Physiological and hygienic assessment of microclimate parameters in office premises of the JSC "Ukrtelecom" in the cold period of the year, Gigiyena naselenykh mists, no. 62, pp. 203-207 (in Ukrainian).

5. Tint, P., Traumann, A., Tuulik-Leisi, V. R. V.,Tuulik, V. 2012, Computer users health risks caused by the simultaneous influence of inadequate indoor climate and monotonous work, Agronomy research biosystems engineering, Issue 1, pp. 261-268.

6. Office ergonomics, 2013, The European Agency for Safety and Health at Work, 14 p., Excess: https://osha. europa.eu/en.

7. Guidelines for using computers. 2013, Preventing and managing discomfort, pain and injury: ACC Publication, Excess: www.acc.co.nz/PRD_EXT_CSMP/ groups/external.../wpc090196.pdf .

8. Aкimenko, V. Ya., Yarygin, A. V. 2009, "Hygienic problems in providing parameters of microclimate and ventilation in modern housing and social buildings",
Gigiyena naselenykh mists, no. 53, pp. 27-33 (in Ukrainian).

9. Dvoryanov, V. V.2012, "Sanitary and epidemiological assessment of systems for ventilation and conditioning in social buildings", Gigiyena i sanitaria, no.1, pp. 16-19 (in Russian).

10. Stebliy, N. M. 2016, Improvement of the criteria on hygienic assessment of ventilation systems in housing buildings, Thesis..., Cand. biol. Sci., Specialty 14.02.01 "Hygiene and Occupational pathology", Institute of Public Healthnamed after O. M. Marzeyev, Kyiv, 19 p. (in Ukrainian).

11. ISO 7730:2011, Ergonomicsofthethermal environment. Analyticaldefinitionandinterpretationofthetherma lcomfortonthebasiccalculationoftheindices PMV i PPD and criteria of the local thermal comfort (ISO 7730:2005, IDT), Minregion of Ukraine України, SE «Ykrarkhbudinform", 76 p. (in Russian).

12. Assessment of a human thermal state with the purpose of grounding hygienic requirements to microclimate at workplaces and to preventive measures on cooling and overheating, 1990, Methodical recommendations № 5168-90, Moscow: Ministry of Health of the USSR, 10 p. (in Russian).

13. Mifflin-St. Leor Equation, 2013, Electronic resource. Excess:http:/lifetransformingdiet.com/Mifflinst-jeor-equation-1b-ft/

14. Zakharenko, M. I. 1978, Microclimate of thermal electric stations in various climatic regions of the USSR, its effect on workers of main occupations and measures on normalization, Thesis..., Cand. med. sci., Kiev, 27 p.

\section{Назаренкко В. І., Чередніченкко І. М., Соловйов О. І., Никифорук О. І., Терешенко П. С.

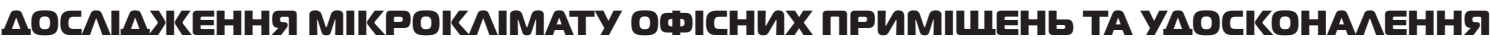 ЙOГO ГIГIEHIЧHOÏ PEГАAMEHTAUIÏ В УКРAÏHI}

Аержавна установа «Інститут медишини праші Нашіональної академії медичних наук України», м. Київ

Bcmyn. Мікроклімат офісних приміщень є важливим чинником виробничого середовища на робочих місцях офісних працівників, що вимагає створення оптимальних умов праці та розробки профілактичних заходів.

Мета дослідження - встановити вплив мікроклімату офісних приміщень на показники теплового стану працюючих та їхню суб'єктивну оцінку комфортності теплового середовища, визначити подальше удосконалення його гігієнічної регламентації.

Матеріали та методи дослідження. Дослідження умов праці проведено в теплий та холодний періоди року за вимогами діючої нормативної документації на 180 робочих місцях офісних працівників (інженери-програмісти, адміністратори систем, начальники секторів, адміністратори задач, інженери-електронники, інженери електрозв'язку) на підприємствах та державних установах м. Києва. Вивчення теплового стану людини (ТСЛ) з суб'єктивною оцінкою комфортності теплового середовища проведено в теплу (червень-серпень) та в холодну пору року (грудень-лютий) у 112 офісних працівників відповідно до МР № 5168-90.

Результати. Встановлено, що температура повітря на робочих місцях офісних працівників виходить за межі діапазону допустимих температур на $1,2-2,4{ }^{\circ} \mathrm{C}$ за діючими в Україні санітарними нормами мікроклімату, але задовольняє вимоги ISO 7730 для теплового середовища категорії В і С (відчуття температурного дискомфорту не більше ніж у 10 та 15 \% користувачів відповідно). Досліджено, що на типовому робочому місці офісного працівника сумарне тепловиділення у середньому складає 452,3 ккал/год або 530 Вт. При цьому на саму людину, що займається офісною працею, у середньому припадає 48 \% загального тепловиділення, а на офісне обладнання - 52 \%. На підставі анкетного опитування розраховано залежність між тепловідчуттям працюючих та температурою повітря в 
офісному приміщенні в теплий та холодний періоди року. Запропоновано заходи зі створення комфортних мікрокліматичних умов.

Висновки. За оцінкою тепловідчуття офісних працівників верхнім порогом появи некомфортної температури повітря в приміщенні в теплий період (влітку) є температура більша ніж $27{ }^{\circ} \mathrm{C}$, у холодний (взимку) - більша ніж $24{ }^{\circ} \mathrm{C}$. Санітарні норми мікроклімату ДСН 3.3.6.042-99 потребують перегляду в частині його оптимальних параметрів, з урахуванням методичних підходів ДСТУ Б ENISO 7730:2011 щодо визначення категорії теплового середовища приміщень та розрахунку кількості незадоволених осіб. Для підтримання оптимальних параметрів відносної вологості повітря в офісному приміщенні рекомендовано застосування ультразвукових зволожувачів повітря типу VitekVT1762W, що мають позитивним побічним ефектом нормалізацію аероіонного складу повітря.

Ключові слова: мікроклімат, офісні приміщення, гігієнічна регламентація

\section{Назаренко В. И., Чередниченко И. М., Соловьев А. И., Никифорук А. И., Терешенко П. С. ИССАЕАОВАНИЕ МИКРОКАИМАТА ОФИСНЫХ ПОМЕШЕНИЙ И СОВЕРШЕНСТВОВАНИЕ ЕГО ГИГИЕНИЧЕСКОЙ РЕГААМЕНТАЦИИ В УКРАИНЕ}

Государственное учрежАение «Институт медицины труда Национальной академии медицинских наук Украины», г. Киев

Вступление. Микроклимат офисных помещений является важным фактором производственной среды, что требует создания оптимальных условий труда и разработки профилактических мероприятий.

Цель исследования - установить влияние микроклимата офисных помещений на показатели теплового состояния работающих и их субъективную оценку комфортности тепловой среды, определить дальнейшее совершенствование его гигиенической регламентации.

Материалы и методы исследования. Исследования условий труда проведены в теплый и холодный периоды года по требованиям действующей нормативной документации на 180 рабочих местах офисных работников (инженерыпрограммисты, администраторы систем, начальники секторов, администраторы задач, инженеры-электронщики, инженеры электросвязи) на предприятиях и государственных учреждениях г. Киева. Изучение теплового состояния человека (ТСЧ) с субъективной оценкой комфортности тепловой среды проведено в теплое (июнь-август) и в холодное (декабрь-февраль) время года у 112 офисных работников в соответствии с МР № 5168-90.

Результаты. Установлено, что температура воздуха на рабочих местах офисных работников выходит на $1,2-2,4{ }^{\circ} \mathrm{C}$ за границы диапазона допустимых температур по действующим в Украине санитарным нормам микроклимата, но, удовлетворяет требования ISO 7730:2005 для помещений категории В и С (ощущение температурного дискомфорта не больше, чем в 10 и $15 \%$ пользователей соответственно). На типовом рабочем месте офисного работника суммарное тепловыделение составляет 452,3 ккал/ч или 530 Вт. При этом на долю человека, занимающегося офисной работой, в среднем приходится 48 \% общего тепловыделения на рабочем месте, а на долю офисного оборудования - 52 \%. На основании анкетного опроса рассчитана зависимость между теплоощущениями работающих и температурой воздуха в офисном помещении в теплый и холодный периоды года. Предложены меры по созданию комфортных микроклиматических условий.

Bыводы. По оценке теплоощущений офисных работников, в среднем, верхним порогом появления некомфортной температуры воздуха в помещении в теплый период (летом) являются температура более $27^{\circ} \mathrm{C}$, в холодный (зимой) более $24{ }^{\circ} \mathrm{C}$. Санитарные нормы микроклимата ДСН 3.3.6.042-99 требуют пересмотра в части его оптимальных параметров, с учетом методических подходов ДСТУ Б ENISO 7730:2011 относительно определения категории тепловой среды помещений и расчета количества недовольных микроклиматом работников. Для поддержания оптимальных параметров относительной влажности воздуха в офисном помещении рекомендовано применение ультразвуковых увлажнителей воздуха типа Vitek VT-1762W, имеющих положительным побочным эффектом нормализацию аэроионного состава воздуха.

Ключевые слова: микроклимат, офисные помещения, гигиеническая регламентация

Надійшла: 10 жовтня 2016 р.

Контактна особа: Назаренко Василь Іванович, ДУ «нститут медицини праці Національної академії медичних наук України», буд. 75, вул. Саксаганського, м. Київ, 01033. Тел.: + 380044 2891215. Електронна пошта: vinazar@ukr.net 